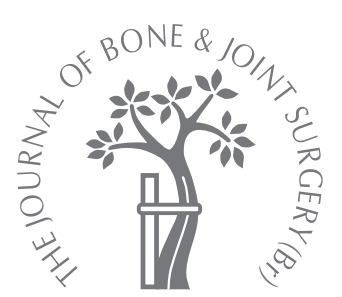

J. F. Quinlan, R. W. G. Watson, G. Kelly, P. M. Kelly, J. M. O’Byrne, J. M. Fitzpatrick

From the Mater Misericordiae Hospital, Dublin, Republic of Ireland

J. F. Quinlan, MCh, AFRCS I, Orthopaedic Registrar P. M. Kelly, FRCS(Orth), Orthopaedic Registrar J. M. O'Byrne, MCh, FRCS(Orth), Consultant Orthopaedic Surgeon J. M. Fitzpatrick, MCh, FRCS I, FRCS G, FRCS,

Professor of Surgery School of Medicine and Medical Science

Mater Misericordiae University Hospital, Eccles Street, Dublin 7, Republic of Ireland.

R. W. G. Watson, PhD, Senior Lecturer School of Medicine and Medical Science

G. Kelly, PhD, Senior Lecturer

School of Mathematical

Sciences

University College Dublin, Belfield, Dublin 4, Republic of Ireland.

Correspondence should be sent to Dr R. W. G. Watson e-mail:

william.watson@ucd.ie

(C)2006 British Editorial Society of Bone and Joint Surgery

doi:10.1302/0301-620X.88B3. $16400 \$ 2.00$

$J$ Bone Joint Surg [Br] 2006;88-B:406-10.

Received 16 February 2005;

Accepted after revision 12 October 2005

\title{
Transforming growth factor-beta (TGF- $\beta$ ) in acute injuries of the spinal cord
}

Injuries to the spinal cord may be associated with increased healing of fractures. This can be of benefit, but excessive bone growth can also cause considerable adverse effects.

We evaluated two groups of patients with fractures of the spinal column, those with neurological compromise $(n=10)$ and those without $(n=15)$, and also a control group with an isolated fracture of a long bone $(n=12)$. The level of transforming growth factor-beta (TGF- $\beta$ ), was measured at five time points after injury (days 1, 5, 10, 42 and 84).

The peak level of $142.79 \mathrm{ng} / \mathrm{ml}$ was found at day 84 in the neurology group (p $<0.001$ vs other time points). The other groups peaked at day 42 and had a decrease at day 84 after injury ( $\mathrm{p} \leq \mathrm{0.001}$ ).

Our findings suggest that TGF- $\beta$ may have a role in the increased bone turnover and attendant complications seen in patients with acute injuries to the spinal cord.

Studies on patients with head injuries have shown that the healing response of fractures is enhanced in direct proportion to the severity of the neurological injury. ${ }^{1}$ While the cause of this is unclear, neural mechanisms have been proposed. The response may be increased to the extent that heterotopic ossification occurs. ${ }^{1,2}$

Heterotopic ossification was first described as a complication of neural disorders in $1918 .^{3}$ It has been associated with a wide variety of spinal disorders and occurs in $15 \%$ to $40 \%$ of patients with injury to the spinal cord. ${ }^{4-6}$ Wittenberg, Peschke and Botel $^{7}$ reported an incidence of $20 \%$. Experimental work to date has concentrated on animal models with induced lesions of central and peripheral nerves. ${ }^{8-10}$

While the benefits of increased fracture healing in patients with such injuries is obvious, there are also side-effects such as joint stiffness and fusion ${ }^{11-16}$ and calculi of the renal tract. ${ }^{17-19}$

The transforming growth factor-beta (TGF$\beta$ ) family is a group of multifunctional polypeptide growth factors ${ }^{20}$ which have a broad range of activity in bone tissue, connective tissue and the immunological system. Bone and platelets contain almost 100 times more TGF$\beta$ than any other tissue and osteoblasts have the greater number of TGF- $\beta$ receptors. ${ }^{21,22}$ In rat calvarial and human osteoblast cell lines, TGF- $\beta$ has been found to increase cell proliferation. ${ }^{23,24}$

Bostrom and Asnis ${ }^{25}$ proposed that the TGF- $\beta$ family has a role in the development, induction and repair of bone. The first in vivo studies demonstrating the stimulatory effects of TGF$\beta$ on the formation of bone used injections of TGF- $\beta$ into fetal rat and mice calvaria and found a marked increase in bone formation. ${ }^{26,27}$ Further animal studies have shown increased osteoblastic stimulation using local and systemic administration of TGF- $\beta^{28-31}$ as well as specific delivery mechanisms such as a methylcellulose gel carrier. ${ }^{32}$ To date, there have been no studies which have examined the level of this known osteogenic cytokine in patients with injuries to the spinal cord.

Our aim, therefore, was to investigate whether patients with acute spinal-cord injuries had increasing levels of TGF- $\beta$ during the immediate period after injury and whether these levels were higher than those seen in similar groups without neurological compromise.

\section{Patients and Methods}

Consecutive patients admitted to our institution were recruited. They were divided into two groups, namely those with fractures of the spinal column and neurological compromise, referred to as the neurology group $(n=10)$, and those with fractures and no neurological compromise, referred to as the no neurology group $(\mathrm{n}=15)$. A further group with an isolated fracture of a long bone, referred to as the long-bone group ( $\mathrm{n}=12$ ), was also included as a control. The groups had similar mean ages and gender distribution. There were ten males 


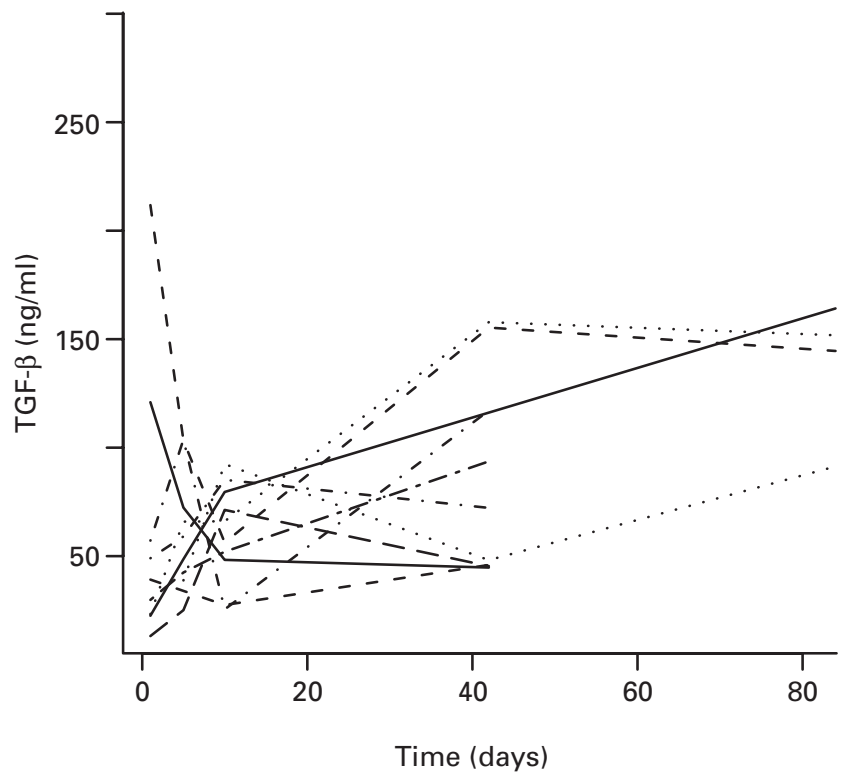

Fig. 1a

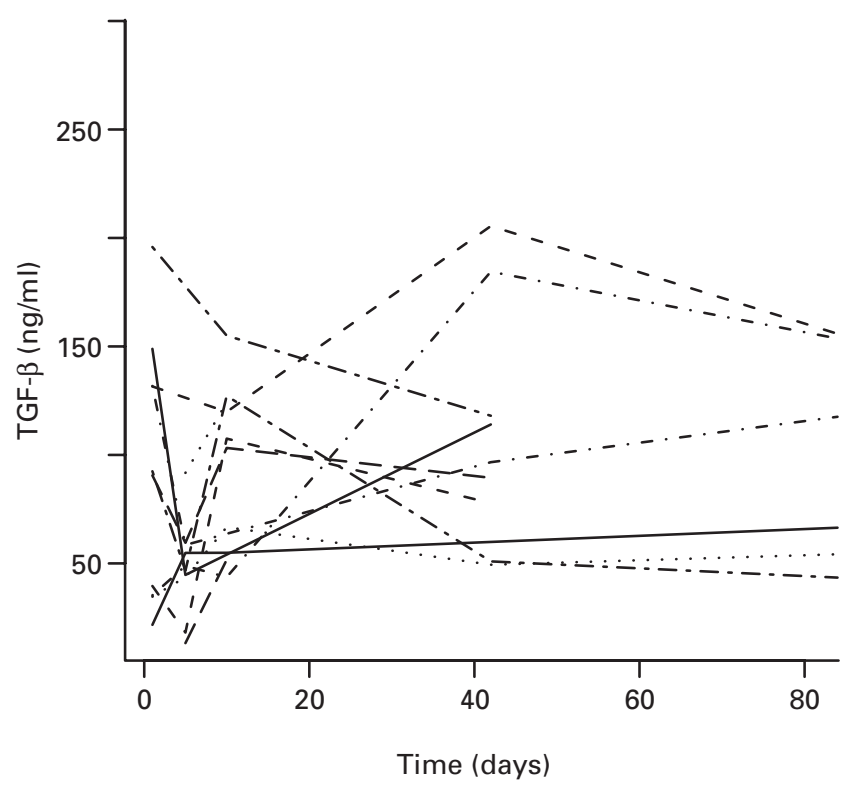

Fig. 1c

and no females with a mean age of 32.9 years in the neurology group, 12 males and three females with a mean age of 31.9 years in the no neurology group and nine males and three females with a mean age of 40 years in the long-bone group. A total of $33(89.2 \%)$ patients had sustained their injuries in either road-traffic accidents (17) or falls (16). The patients in the neurology and no neurology groups had fractures at similar vertebral levels.

The study had been approved by the local ethics committee and written consent had been obtained from the patients.

The level of TGF- $\beta$ assessed from venous blood samples was taken at five time points after the injury: day 1 ( 0 to 2 ),

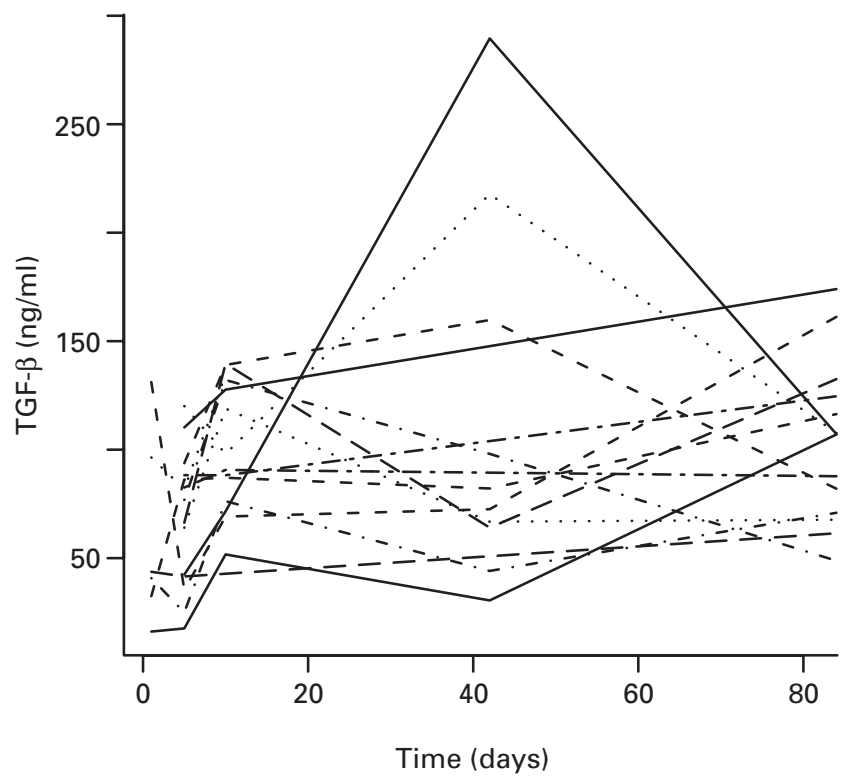

Fig. 1b

The level of TGF- $\beta$ per patient per time point in a) the neurology, b) the no neurology and $\mathrm{c}$ ) the control groups.

day 5 (4 to 6), day 10 (9 to 11 ), day 42 (35 to 49 ) and day 84 ( 77 to 91 ). A total of 146 individual serum samples was obtained, representing $78.9 \%$ of the total available samples. The main reasons for missing samples were delay in transfer to our tertiary referral unit at the first time point and failure of follow-up at the later time points (Table I).

The samples were transported on ice and centrifuged at $1100 \mathrm{rpm}$ for ten minutes and then separated and frozen at $-80^{\circ} \mathrm{C}$ for batch analysis.

Each serum sample was analysed in duplicate for TGF- $\beta$ using a commercially-available enzyme-linked immunosorbent assay (ELISA) kit ( $+\mathrm{D}$ Systems Europe Ltd, Abingdon, UK) in accordance with the manufacturer's 
instructions. All samples were taken from the $-80^{\circ} \mathrm{C}$ freezer and thawed at room temperature. The results were expressed as $\mathrm{ng} / \mathrm{ml}$.

Statistical analysis. The TGF- $\beta$ levels were examined giving a profile for each subject. A quadratic function of time was fitted to the data of each subject separately, resulting in estimates for the subject-specific intercept and the two subjectspecific slopes. This was done using a mixed-effects model through the mixed procedure in the statistical software SAS (SAS Institute Inc., Cary, North Carolina). The fixed effects were the regression parameters (intercept and two slopes) which were assumed to be the same for all subjects in a particular group (yielding mean profiles), while the random effects were the subject-specific regression parameters. A mean profile which was quadratic over time was fitted to each group and subjects within a group varied randomly about this mean. The repeated observations over time within each subject were specified to have an unstructured covariance matrix. Simpler forms for the covariance matrix were also fitted. Checking of the model was carried out by examination of the studentised residuals, influence statistics and normal probability plots. Restricted maximum likelihood was used to estimate the model. ${ }^{33} \mathrm{~A} \mathrm{p}$ value of less than 0.05 was considered significant.

\section{Results}

The results for the neurology group at the first three time periods i.e. day 1 ( 9 samples analysed), day 5 (9) and day 10 (10) after injury, were similar with means of $73.91 \mathrm{ng} / \mathrm{ml}$, $73.15 \mathrm{ng} / \mathrm{ml}$ and $71.54 \mathrm{ng} / \mathrm{ml}$, respectively. At day 42 (9) after injury, the value rose to a mean of $95.66 \mathrm{ng} / \mathrm{ml}$.

The mean level in this group rose again and peaked at day 84 (4) after injury at $142.79 \mathrm{ng} / \mathrm{ml}$. The level then increased linearly over time $(\mathrm{p}<0.001)$. The profiles over time for each patient are shown in Figure 1.

A different pattern was seen in the no neurology group. The lowest recorded mean level of $64.03 \mathrm{ng} / \mathrm{ml}$ was seen at day 1 (6) after injury. The level peaked at day 42 (10) after injury at a mean of $112.52 \mathrm{ng} / \mathrm{ml}$. At the final time point, day 84 (14) after injury, it fell slightly to $103.51 \mathrm{ng} / \mathrm{ml}$. The linear progression noted in the neurology group thus was not seen in the no neurology group and this was significant, i.e. in the no neurology group, the progression was quadratic ( $\mathrm{p}=0.001$; Fig. 2$)$.

In the long-bone group there was an early rise at day 1 (10) after injury with a mean value of $96.31 \mathrm{ng} / \mathrm{ml}$. At day 5 (11) and day 10 (10) after injury the level was $54.57 \mathrm{ng} /$ $\mathrm{ml}$ and $99.32 \mathrm{ng} / \mathrm{ml}$, respectively.

Similar to the results in the no neurology group, the mean level in the long-bone group peaked at day 42 (9) after injury at $112.71 \mathrm{ng} / \mathrm{ml}$. At day 84 (6), it decreased to $102.28 \mathrm{ng} / \mathrm{ml}$. These results did not represent a significant linear increase $(\mathrm{p}=0.001)$ as was seen in the neurology group.

When the results of the various groups were analysed at day 1 after injury, it was seen that the mean level in the neu-

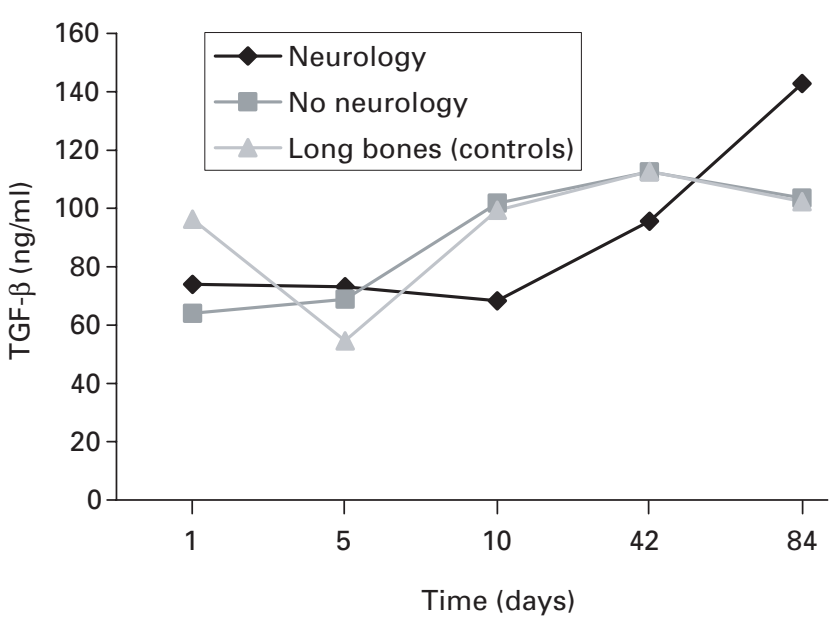

Fig. 2

The level of TGF- $\beta$ in each group throughout the period of study.

Table I. Patients lost to follow-up at relevant time intervals

\begin{tabular}{llllll}
\hline & \multicolumn{5}{l}{ Time (days) } \\
\cline { 2 - 6 } & $\mathbf{1}$ & $\mathbf{5}$ & $\mathbf{1 0}$ & $\mathbf{4 2}$ & $\mathbf{8 4}$ \\
\hline Neurology & 1 & 1 & 0 & 1 & 6 \\
No neurology & 9 & 0 & 1 & 5 & 1 \\
Long bone & 2 & 1 & 2 & 3 & 6 \\
\hline
\end{tabular}

rology group (9 samples analysed) $(73.91 \mathrm{ng} / \mathrm{ml})$ was higher than that in the no neurology group (6) $(64.03 \mathrm{ng} /$ $\mathrm{ml})$, but lower than that of the long-bone group (10) (96.31 ng/ml) (Fig. 2).

A similar pattern was seen at day 5 after injury. The mean recorded level of TGF- $\beta$ for the neurology (9), no neurology (15) and long-bone groups (11) was $73.15 \mathrm{ng} /$ $\mathrm{ml}, 68.79 \mathrm{ng} / \mathrm{ml}$ and $54.57 \mathrm{ng} / \mathrm{ml}$, respectively.

There was a different trend at day 10 after injury in the neurology group (10) which had a lower mean level $(68.27$ $\mathrm{ng} / \mathrm{ml})$ than the no neurology group (14) $(101.75 \mathrm{ng} / \mathrm{ml})$ and the long-bone group (10) $(99.32 \mathrm{ng} / \mathrm{ml})$.

The mean level of TGF- $\beta$ recorded at day 42 after injury was not significantly different. The level recorded for the neurology group (9), no neurology group (10) and longbone group (9) was $95.66 \mathrm{ng} / \mathrm{ml}, 112.52 \mathrm{ng} / \mathrm{ml}$ and 112.71 $\mathrm{ng} / \mathrm{ml}$, respectively. However, in the case of the last two groups, the results at day 42 after injury represented the peak values seen.

At day 84 after injury, the mean value for the neurology group (4) was $142.79 \mathrm{ng} / \mathrm{ml}$ which represented a significant linear increase over the five time periods $(\mathrm{p}<0.001)$. The mean level of $103.51 \mathrm{ng} / \mathrm{ml}$ in the no neurology group and of $102.28 \mathrm{ng} / \mathrm{ml}$ in the long-bone group (6) represented a 
decrease from their respective values at 42 days after injury, thus not showing a linear increase $(p \leq 0.001)$ as was seen in the neurology group.

The diagnostic checks revealed no departures from the fitted model.

\section{Discussion}

In our study the patients in the neurology group all received intravenous methylprednisolone according to the protocol of the American Spinal Injuries Association ${ }^{34,35}$ (30 mg/kg in $500 \mathrm{ml}$ of dextrose over 15 minutes followed by an infusion of $5.4 \mathrm{mg} / \mathrm{kg} /$ per hour in dextrose continued for 23 hours).

The uniformity of the levels of TGF- $\beta$ at days 1,5 and 10 after injury suggests that the steroids are influencing the levels of TGF- $\beta$. This makes comparison between the three groups difficult and liable to bias.

A further confounding factor was the effect on inflammatory markers of intramedullary reaming in the long-bone group. This was performed in 11 of the 12 patients. ${ }^{36}$

At day 42 there was no difference between the mean level in the three groups.

At day 84 the mean level for the neurology group was at its peak. This represented a statistically-significant linear increase in TGF- $\beta$ throughout the time points in this group $(\mathrm{p}<0.001)$ and contrasted with the level in the other two groups which peaked at day 42 after injury and thus showed a significant non-conformity with the observed linear increase $(\mathrm{p} \leq 0.001)$.

We believe that this increase at day 84 after injury validated the aims for our experiment. The unwanted sideeffects of increased bone turnover seen in the patients in the neurology group are long-term problems and our results suggest that TGF- $\beta$ may have a role as a clinical marker. In addition, the fact that heterotopic ossification can be present as early as four weeks after spinal injury ${ }^{37}$ suggests that the process is well underway by 84 days after injury. A further long-term study is necessary to determine if these effects persist.

The clinical significance of these results is further suggested by virtue of the relative uniformity of the results within each group at each time point as shown by the respective SDs. When the concentration of TGF- $\beta$ in relation to osteoblasts ${ }^{21,22}$ and the effect that it has on increased bone turnover and fracture healing are considered, ${ }^{23,24,29,30}$ we believe that these results support our theory that TGF- $\beta$ has an active role in the mediation of the side-effects of acute injuries to the spinal cord. Furthermore, we feel that the possible role of TGF- $\beta$ as a marker for increased bone turnover in patients with such injuries warrants further investigation.

We wish to express our gratitude to Dr. T. Brabazon, PhD, Statistician, Department of Accountancy, University College, Dublin for his help in the original statistical analysis used in this paper.

This work was funded by the generous financial support of the Cappagh Hospital Trust (Cappagh National Orthopaedic Hospital, Finglas, Dublin 11, Republic of Ireland).
No benefits in any form have been received or will be received from a commercial party related directly or indirectly to the subject of this article.

\section{References}

1. Spencer RF. The effect of head injury on fracture healing: a quantitative assessment. $J$ Bone Joint Surg [Br] 1987;69-B:525-8.

2. Bidner SM, Rubins IM, Desjardins JV, Zukor DJ, Goltzman D. Evidence for a humoral mechanism for enhanced osteogenesis after head injury. J Bone Joint Surg [Am] 1990;72-A:1144-9.

3. Dejerine MME, Ceillier A. Paraosteoarthropaties des paraplegiques par lesions medullaires (etudes clinique et radiographique). Ann Med 1918;5:497-535.

4. Damanski M. Heterotopic ossification in paraplegia. J Bone Joint Surg [Br] 1961; 43-B:286-99.

5. Hardy AG, Dickson JW. Pathological ossification in traumatic paraplegia. J Bone Joint Surg [Br] 1963;45-B:76-87.

6. Wharton GW, Morgan TH. Ankylosis in the paralysed patient. J Bone Joint Surg [Am] 1970;52-A:105-12.

7. Wittenberg RH, Peschke U, Botel U. Heterotopic ossification after spinal cord injury: epidemiology and risk factors. J Bone Joint Surg [Br] 1992;74-B:215-18.

8. Ato H, Eerola E, Aho AJ, Pentinen R. Healing of experimental fractures in the denervated limbs of the rat. Clin Orthop 1981;155:211-17.

9. Aro $\mathbf{H}$. Effect of nerve injury on fracture healing: callus formation studied in the rat. Acta Orthop Scand 1985;56:233-7.

10. Miyamoto T. An experimental study on fracture healing in paraplegic rats. Nippon Seikeigeka Gakkai Zasshi 1987;61:1135-45 (in Japanese).

11. Freehafter AA. Limb fractures in patients with spinal cord injury. Arch Phys Med Rehabil 1995;76:823-7.

12. Hsu JD, Sakimura I, Stauffer ES. Heterotopic ossification around the hip joint in spinal cord injured patients. Clin Orthop 1975;112:165-9.

13. Tibone J, Sakimura I, Nickel VL, Hsu JD. Heterotopic ossification around the hip in spinal cord-injured patients: a long-term follow-up study. J Bone Joint Surg [Am] 1978;60-A:769-73.

14. Wharton GW. Heterotopic ossification. Clin Orthop 1975;112:142-9.

15. Meiners T, Abel R, Bohm V, Gerner HJ. Resection of heterotopic ossification of the hip in spinal cord injured patients. Spinal Cord 1997;35:443-5.

16. Garland DE, Orwin JF. Resection of heterotopic ossification in patients with spinal cord injuries. Clin Orthop 1989;242:169-76.

17. Vaidyanathan S, Soni BM, Biering-Sorenson F, et al. Recurrent bilateral renal calculi in a tetraplegic patient. Spinal Cord 1998;36:454-62.

18. Issa MM, McNamara DE, Myrick SE, et al. Surgical challenge of massive bilateral staghorn renal calculi in a spinal cord injury patient. Urol Int 1998;61:247-50.

19. Levy DA, Resnick MI. Management of urinary stones in the patient with spinal cord injury. Urol Clin North Am 1993;20:435-42.

20. Burt DW. Evolutionary grouping of the transforming growth factor-beta superfamily Biochem Biophys Res Commun 1992;184:590-5.

21. Robey PG, Young MF, Flanders KC, et al. Osteoblasts synthesise and respond to transforming growth factor-type beta (TGF-beta) in vitro. J Cell Biol 1987;105:457-63.

22. Sporn MB, Roberts AB. The multifunctional nature of growth factors. In: Sporn MB Roberts $A B$, eds. Handbook of experimental pharmacology: peptide growth factors and their receptors. New York: Springer-Verlag, 1990:3-15.

23. Canalis E. Effect of growth factors on bone cell replication and differentiation. Clin Orthop 1985;193:246-63.

24. Rickard DJ, Gowen M, MacDonald BR. Proliferative responses to estradiol, IL-1 alpha and TGF beta by cells expressing alkaline phosphatase in human osteoblastlike cell cultures. Calcif Tissue Int 1993;52:227-33.

25. Bostrom MP, Asnis P. Transforming growth factor in fracture repair. Clin Orthop 1998;355(Suppl):124-31.

26. Noda M, Camilliere JJ. In vivo stimulation of bone formation by transforming growth factor-beta. Endocrinology 1989;124:2991-4.

27. Joyce ME, Roberts AB, Sporn MB, Bolander ME. Transforming growth factor and the initiation of chondrogenesis and osteogenesis in the rat femur. J Cell Biol 1990;110:2195-207.

28. Miyauchi A, Kruska KA, Greenfield EM, et al. Osteoclast cytosolic calcium, regulated by voltage-gated calcium channels and extracellular calcium, controls podosome assembly and bone resorption. J Cell Biol 1990;111:2543-52.

29. Aufdemorte TB, Fox WC, Holt GR, et al. An intraosseous device for studies of bone-healing: the effect of transforming growth factor-beta. J Bone Joint Surg [Am] 1992;74-A:1153-61.

30. Lind M, Schumacker B, Soballe K, et al. Transforming growth factor enhances fracture healing in rabbit tibiae. Acta Orthop Scand 1993;64:553-6. 
31. Sumner DR, Turner TM, Purchio AF, et al. Enhancement of bone ingrowth by transforming growth factor-beta. J Bone Joint Surg [Am] 1995;77-A:1135-47.

32. Beck LS, Deguzman L, Lee WP, et al. TGF- $\beta$ induces bone closure of skull defects. J Bone Min Res 1991;6:1257-65.

33. Verbecke G, Molenberghs G. Linear mixed models in practice. In: Verbecke G, Molenberghs G, eds. Lecture notes in statistics. New York: Springer-Verlag, 1997.

34. Bracken MB, Shepard MJ, Collins WF, et al. A randomized controlled trial of methylprednisolone or naloxone in the treatment of acute spinal cord injuries: results of the second national acute spinal cord injury study. N Engl J Med 1990;322: 1405-11.
35. Bracken MB, Shepherd MJ, Holford TR, et al. Administration of methyprednisolone for 24 or 48 hours or tirilazad mesylate for 48 hours in the treatment of acute spinal cord injuries: results of the third national acute spinal injury randomized controlled trial. JAMA 1997;277:1597-604.

36. Pape HC, Grimme K, Van Griensven M, et al. Impact of intramedullary instrumentation versus damage control for femoral fractures on immunoinflammatory parameters: prospective randomized analysis by the EPOFF Study Group. J Trauma 2003;55: 7-13.

37. Banovac K, Gongalez F. Evaluation and management of heterotopic ossification in patients with spinal cord injury. Spinal Cord 1997;35:158-62. 